\title{
Enantiomeric Resolution of Drugs and Metabolites in Polysaccharide- and Protein-Based Chiral Stationary Phases
}

\author{
Pierina S. Bonato ${ }^{* a}$, Renato Bortocan ${ }^{a}$, Cristiane M. Gaitani ${ }^{a}$, Fernanda O. Paias ${ }^{b}$, Maria H. Iha $^{b, c}$ \\ and Rodrigo P. Lima ${ }^{a}$ \\ ${ }^{a}$ Faculdade de Ciências Farmacêuticas de Ribeirão Preto, Universidade de São Paulo, Avenida do Café, s/n, \\ 14040-903, Ribeirão Preto - SP, Brazil \\ ${ }^{b}$ Faculdade de Filosofia, Ciências e Letras de Ribeirão Preto, Universidade de São Paulo, Avenida dos Bandeirantes, \\ 3900, 14040-901, Ribeirão Preto - SP, Brazil \\ ${ }^{c}$ Instituto Adolfo Lutz, Laboratório I de Ribeirão Preto, Rua Minas, 877, 14085-410, Ribeirão Preto - SP, Brazil
}

\begin{abstract}
Várias fases estacionárias baseadas em derivados de polissacarídeos e proteínas foram avaliadas para a resolução de alguns fármacos quirais e seus metabólitos. As fases estacionárias baseadas em polissacarídeos CHIRALCEL OD-H, CHIRALCEL OB-H, CHIRALCEL OJ, CHIRALPAK AD e CHIRALPAK AS foram avaliadas em condições de fase normal, usando hexano:2-propanol como fase móvel. Dietilamina ou ácido trifluoracético foram adicionados para melhorar a simetria dos picos. As colunas CHIRALCEL OJ-R, CHIRALCEL OD-R e CHIRALCEL OD-H foram avaliadas em condições de fase reversa, usando acetonitrila:água ou acetonitrila: $\mathrm{NaClO}_{4}$. As fases estacionárias baseadas em proteínas CHIRAL AGP e ULTRON ES-OVM foram usadas com fases móveis consistindo de soluções tampão adicionadas de modificadores orgânicos. Entre as fases estacionárias baseadas em derivados de polissacarídeos, a CHIRALPAK AD mostrou melhor resolução de quase todos os fármacos e metabólitos estudados. A coluna ULTRON ES-OVM foi particularmente útil para a resolução dos quatro estereoisômeros da tioridazina-2-sulfóxido.
\end{abstract}

Several chiral stationary phases based on polysaccharide derivatives and proteins were evaluated for the resolution of some chiral drugs and their metabolites. The polysaccharide-based stationary phases CHIRALCEL OD-H, CHIRALCEL OB-H, CHIRALCEL OJ, CHIRALPAK AD and CHIRALPAK AS were evaluated under normal phase conditions, using hexane:2-propanol or hexane:ethanol as mobile phase. Diethylamine and trifluoracetic acid were also added to improve peak shape. The CHIRALCEL OJ-R, CHIRALCEL OD-R and CHIRALCEL OD-H columns were evaluated under reversed-phase conditions, using acetonitrile: $\mathrm{H}_{2} \mathrm{O}$ or acetonitrile: $\mathrm{NaClO}_{4}$ solution. The protein- based stationary phases, CHIRAL AGP and ULTRON ES-OVM columns were used with mobile phases consisting of a buffer solution supplemented with an organic modifier. Among the polysaccharide-based stationary phases, CHIRALPAK AD provided better resolution for almost all drugs and metabolites studied. The ULTRON ES-OVM column was particularly suitable for the resolution of the four enantiomers of thioridazine-2-sulfoxide.

Keywords: polysaccharide-based stationary phases, protein- based stationary phases, drugs, metabolites, enantioselective analysis

\section{Introduction}

Stereoselectivity in drug disposition and drug action is now a well established issue and plays an important role in drug development both from the viewpoint of the

* e-mail: psbonato@fcfrp.usp.br pharmaceutical industry and of regulatory authorities. As a result, the development of selective and sensitive analytical techniques that can discriminate between optical isomers is essential for the investigation of the pharmacokinetic and pharmacodynamic properties of chiral drugs, as well as for enantiomeric purity determination..$^{1-3}$ High performance liquid chromatography has been the most widely used technique for the enantioselective analysis of chiral drugs, mainly by using chiral stationary phases. 
Over the last two decades a large number of chiral stationary phases have been described in the literature and some of them are commercially available. Among them, those based on polysaccharides ${ }^{4,5}$ and proteins ${ }^{6}$ have broad application due to their stability, efficiency and high resolving ability. Polysaccharide phases are also particularly well suited for preparative scale enantiomeric separations. ${ }^{7}$ Polysaccharide phases are prepared by coating cellulose or amylose derivatives (acetates, benzoates or carbamates) on a pretreated silica gel matrix and could be used under normal or reversed phase conditions. The main chiral adsorbing sites on acetate and benzoate derivatives are considered to be the polar carbonyl group which can interact with racemates through hydrogen bonding and dipole-dipole interaction. In carbamate derivatives, the solute can interact with the $\mathrm{C}=\mathrm{O}$ and $\mathrm{NH}$ groups through hydrogen bonding and with the $\mathrm{C}=\mathrm{O}$ moiety through dipole-dipole interaction. ${ }^{8}$ The resolution ability depends on the kind of derivative as well as on the substituents in the phenyl groups. Differences in the higher-order structures among cellulose and amylose are also responsible for differences in chiral discrimination..$^{8-10}$

Due to their broad applicability and to the fact that the use of buffered aqueous mobile phases is compatible with biological fluids, protein-based columns have become very popular. Commercially available columns have been prepared with bovine serum albumin, human serum albumin, cellobiohydrolase, human $\alpha$-1-acid glycoprotein and ovomucoid proteins. Among these, columns based on $\alpha$-1-acid glycoprotein (CHIRAL AGP) and ovomucoid protein (ULTRON ES-OVM) have shown a wide range of applicability. ${ }^{11,12}$

Due to the highly complex structure of the protein, the chiral discrimination mechanism is only incompletely known. It has been suggested that retention and enantioselectivity in protein-based chiral stationary phases depend on hydrophobic interactions, hydrogen bonding, ionic bonding and ion-pairing interactions. ${ }^{13}$

In the present study, several polysaccharide- and protein-based chiral columns were evaluated for the resolution of some drugs and their metabolites (Figure 1). The influence of mobile phase composition on retention and chiral resolution was also evaluated. These drugs and metabolites were selected because their pharmacodynamic properties and kinetic disposition are stereoselective. It is worth mentioning that the resolution of thioridazine, primaquine and carboxyprimaquine using these columns has not been previously reported in the literature. Moreover, this is the first paper reporting the resolution of the enantiomers of hydroxymebendazole, the chiral metabolite of mebendazole.

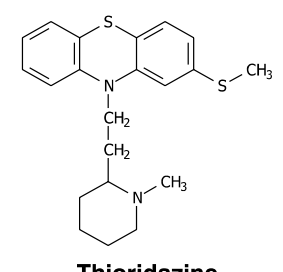

Thioridazine

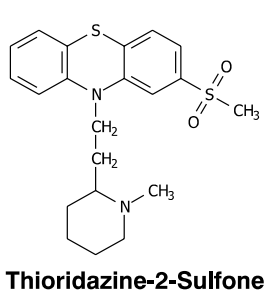

Thioridazine-2-Sulfone

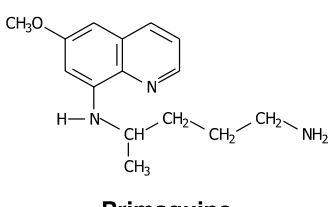

Primaquine

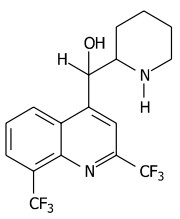

Mefloquine

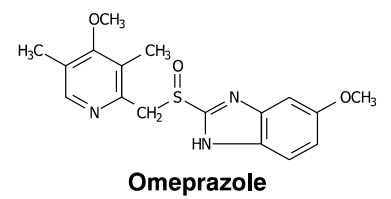

Figure 1. Chemical structures of the drugs and metabolites

\section{Experimental}

\section{Chemicals and reagents}

The racemic drugs and metabolites were kindly supplied by the following pharmaceutical industries: Novartis Pharma Inc., Basle, Switzerland (thioridazine and its metabolites); Janssen-cilag N.V., Berchem, Belgium (hydroxymebendazole); Astra Zeneca do Brasil Ltda., Cotia, Brazil (omeprazole); Laboratórios Biosintética Ltda., São Paulo, Brazil (atenolol); F. Hoffmann-La Roche Ltda, Basel, Switzerland (mefloquine). Primaquine and carboxyprimaquine were a generous gift from the Walter Reed Army Institute of Research (Rockville, Maryland, USA). 
Hexane, 2-propanol, methanol, ethanol and acetonitrile were HPLC grade and were purchased from Merck (Rio de Janeiro, Brazil). All other chemicals were of analytical grade. Water was purified in a Milli-Q-plus reagent water system (Millipore, São Paulo, Brazil).

\section{Equipment and chromatographic conditions}

The HPLC system consisted of a Shimadzu instrument (Kyoto, Japan) equipped with a model LC-10AS solvent pump, a 7125 Rheodyne injector with a 20 or $50 \mu \mathrm{L}$ loop, a model LC-10 A variable UV-Visible detector and a model CR6-A integrator.

The chiral columns used for the enantioselective resolution of the drugs and metabolites were purchased from Chiral Technologies, Exton, PA, USA (CHIRALCEL OD-H, $150 \times 4.6 \mathrm{~mm}$, I.D., $5 \mu \mathrm{m}$ particle size, CHIRALCEL OB-H, $150 \times 4.6 \mathrm{~mm}$, I.D., $5 \mu \mathrm{m}$ particle size, CHIRALCEL OJ , $250 \times 4.6 \mathrm{~mm}$, I.D., $10 \mu \mathrm{m}$ particle size, CHIRALCEL ODR, 250 x $4.6 \mathrm{~mm}$, I.D., $10 \mu \mathrm{m}$ particle size, CHIRALCEL OJ$\mathrm{R}, 150 \times 4.6 \mathrm{~mm}$, I.D., $5 \mu \mathrm{m}$ particle size, CHIRALPAK AD, $250 \times 4.6 \mathrm{~mm}$, I.D., $10 \mu \mathrm{m}$ particle size and CHIRALPAK AS, 250 x $4.6 \mathrm{~mm}$, I.D., $10 \mu \mathrm{m}$ particle size), J.T. Baker, Phillipsburg, NJ, USA (CHIRAL AGP, 150 x 4.0 mm, I.D., $5 \mu \mathrm{m}$ particle size) and Rockland Technologies, Newport, DE, USA (ULTRON ES-OVM, 150 x 4.6 mm, I.D., $5 \mu \mathrm{m}$ particle size).

\section{Chromatographic procedure}

Standard solutions were prepared in methanol at the concentration of $100.0 \mu \mathrm{g} \mathrm{mL}^{-1}$ and were stored at $-20{ }^{\circ} \mathrm{C}$. Immediately before the analysis, $25 \mu \mathrm{L}$ of the solutions were evaporated to dryness, the residues were dissolved in 100 $\mu \mathrm{L}$ of the mobile phase and 20 or $50 \mu \mathrm{L}$ were chromatographed. Before the analysis, the columns were equilibrated by eluting approximately $100 \mathrm{~mL}$ of the mobile phase. The wavelengths used for the detection were chosen based on the $\lambda_{\text {max }}$ for each compound analyzed. All separations were performed in a climatized room $\left(22 \pm 2{ }^{\circ} \mathrm{C}\right)$. When the columns were not in use, the mobile phases were replaced with the storage solvent recommended by the column suppliers.

Chromatographic retention was evaluated using the retention factor $(k)$, estimated as $\left(t_{R}-t_{o}\right) / t_{o}$, where $t_{R}$ is the retention time of each enantiomer and $t_{0}$ is the first significant baseline disturbance, corresponding to the retention time of a non retained solute. The separations were characterized by the enantioselective factor $(\alpha)$, estimated as $\mathrm{k}_{2} / \mathrm{k}_{1}$, and by resolution (Rs), estimated as 2 $\left(\mathrm{t}_{\mathrm{R} 2}-\mathrm{t}_{\mathrm{R} 1}\right) /\left(\mathrm{w}_{\mathrm{b} 1}+\mathrm{w}_{\mathrm{b} 2}\right)$, where $\mathrm{t}_{\mathrm{R} 2}$ and $\mathrm{t}_{\mathrm{R} 1}$ are the retention times for the second and first eluted enantiomer, respectively and $\mathrm{w}_{\mathrm{b} 1}$ and $\mathrm{w}_{\mathrm{b} 2}$ are their bandwidth at the baseline.

\section{Results and Discussion}

\section{Polysaccharide phases}

Table 1 shows the enantioselective factors obtained for all drugs and metabolites analyzed in seven polysaccharidebased stationary phases. The mobile phases used were different for which drug and type of stationary phase and were selected among the mobile phases that resulted in better resolution. Some of these mobile phases that are important for the discussion of our results or that resulted resolution

Table 1. Enantioselective factors $(\alpha)$ obtained for the drugs and metabolites analyzed in polysaccharide- and protein-based stationary phases

\begin{tabular}{lclllllllcc}
\hline \multirow{2}{*}{ Drug/metabolite } & \multicolumn{10}{c}{ Chiral column } \\
\cline { 2 - 10 } & OB-H & OJ & OD-H & AD & AS & OD-R & OJ-R & CHIRAL AGP & ULTRON ES-OVM \\
\hline Thioridazine & 1.00 & 1.08 & 1.00 & $1.15^{*}$ & 1.00 & 1.00 & - & 1.30 & 1.00 \\
Thioridazine-2-sulfone & 1.00 & $1.90^{\mathrm{a}}$ & $1.16^{*}$ & 1.08 & 1.09 & 1.00 & - & 1.00 & 1.46 \\
Thioridazine-2-sulfoxide** & 1.00 & $1.31^{\mathrm{b}}$ & 1.00 & 1.33 & $2.48^{\mathrm{i}}$ & 1.00 & - & 1.24 & $1.85^{*}$ \\
Thioridazine-5-sulfoxide** & 1.00 & 1.14 & $1.66^{*}$ & 1.21 & 1.17 & $1.16^{*}$ & - & $1.28^{*}$ & 1.00 \\
Primaquine & - & 1.08 & $1.78^{\mathrm{c}}$ & $1.35^{\mathrm{f}}$ & 1.39 & $1.41^{*}$ & 1.00 & $1.12^{*}$ & $1.68^{*}$ \\
Carboxyprimaquine & - & $1.56^{*}$ & 1.05 & $1.35^{\mathrm{g}}$ & 1.12 & $1.14^{*}$ & $1.40^{*}$ & 1.39 & 1.18 \\
Mefloquine & 1.00 & 1.00 & $1.98^{\mathrm{d}}$ & $1.63^{\mathrm{h}}$ & $2.57^{*}$ & - & - & $2.16^{\mathrm{j}}$ & - \\
Atenolol & 1.00 & 1.09 & $1.73^{*}$ & - & 1.09 & 1.00 & 1.00 & 1.16 & 1.00 \\
Omeprazole & $1.36^{*}$ & 1.00 & 1.31 & $1.59^{*}$ & $2.20^{*}$ & 1.00 & 1.05 & $2.17^{\mathrm{k}}$ & - \\
Hydroxymebendazole & 1.00 & 1.15 & $1.50^{\mathrm{e}}$ & $1.66^{*}$ & 1.13 & 1.12 & 1.00 & - & 1.00 \\
\hline
\end{tabular}

*, mobile phases reported in figures legends; **enantioselective factor for the major par of enantiomers; -, column not evaluated for this drug/ metabolite; (a) hexane:2-propanol $(90: 10)+0.1 \%$ DEA, Rs $=1.85$; (b) hexane:ethanol $(90: 10)+0.1 \%$ DEA, Rs = 3.10; (c) hexane:ethanol $(95: 5)+0.1 \%$ TFA, Rs = 2.86; (d) hexane:2-propanol (95:5) + 0.05\% TFA, Rs = 3.82; (e) hexane:ethanol (90:10), Rs = 1.58; (f) hexane:2propanol $(95: 5)+0.3 \%$ TFA, Rs $=1.91 ;(\mathrm{g})$ hexane:2-propanol $(95: 5)+0.3 \%$ TFA, Rs $=3.75$; $(\mathrm{h})$ hexane:ethanol $(95: 05)+0.025 \%$ DEA, Rs $=5.60$; (i) hexane:ethanol $(90: 10)+0.1 \%$ DEA, Rs $=7.07$; (j) phosphate $10 \mathrm{mmol} / \mathrm{L}, \mathrm{pH}$ 4.0:acetonitrile (93:7) Rs = 2.37; (k) phosphate $20 \mathrm{mmol} \mathrm{L}^{-1}$, pH 4.7:acetonitrile (93:7) Rs $=1.88$. 
higher than 1.5 are summarized in Table 1 or in the figures legends. Among the drugs and metabolites evaluated, only omeprazole could be resolved on the CHIRALCEL OB-H column, a cellulose tribenzoate-derived chiral stationary phase (Figure 2). The introduction of substituents in the phenyl moiety of the cellulose derivative increases the resolving ability of the chiral stationary phase. According to Yashima \& Okamoto, ${ }^{8}$ benzoate derivatives having electron-donating substituents, such as methyl groups, have shown better chiral recognition. For the drugs evaluated in the present study, we observed that the CHIRALCEL OJ column (cellulose tris(4-methylbenzoate)) was well suited for the baseline resolution of thioridazine-2-sulfone and carboxyprimaquine (Table 1). The evaluation of this chiral selector under reversed phase conditions also resulted in the resolution of carboxyprimaquine (Figure 3 ).

Tris (3,5-dimethylphenylcarbamate) derivatives of cellulose (CHIRALCEL OD-H) and amylose (CHIRALPAK $\mathrm{AD})$ have proved to be the most versatile chiral stationary phases for the resolution of chiral drugs. ${ }^{8}$ All drugs and metabolites studied could be satisfactory resolved on at least one of these two columns. In general, the CHIRALPAK AD column resulted in better resolution (Table 1), but thioridazine-2-sulfone could only be satisfactory resolved on the CHIRALCEL OD-H column (Figure 4). The different behavior observed for these two columns was explained by the difference in higher-order structure, i.e. a left-handed 3/ 2 and 4/1 helical structure for cellulose and amylose derivatives, respectively. ${ }^{8,14}$
When the cellulose tris (3,5-dimethylphenylcarbamate) stationary phase was used under reversed phase conditions (CHIRALCEL OD-R), the chiral discrimination behavior also changed, being usually worse than under normal phase conditions (CHIRALCEL OD-H), as can be seen for thioridazine-5-sulfoxide (Figure 5). The chiral resolution of atenolol was only possible by using the CHIRALCEL OD-H column (Table 1 and Figure 5).

The supplier of CHIRALCEL OD-H column recommends its use only under normal phase conditions, but when this column was converted to reversed phase mode, according

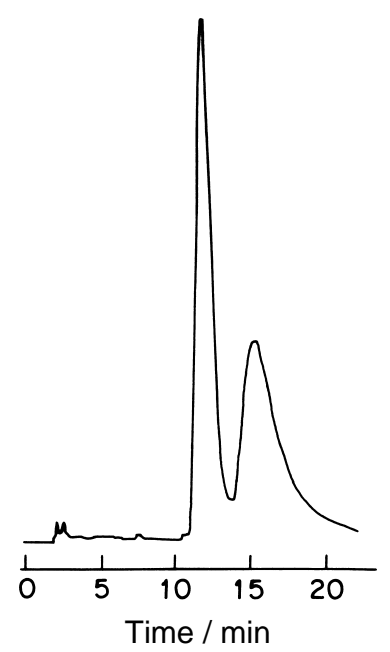

Figure 2. Chiral resolution of omeprazole on CHIRALCEL OB-H column. Mobile phase: hexane:ethanol (93:7, v/v) at a flow rate of $1.0 \mathrm{~mL} \mathrm{~min}^{-1}$; detection at $302 \mathrm{~nm}$

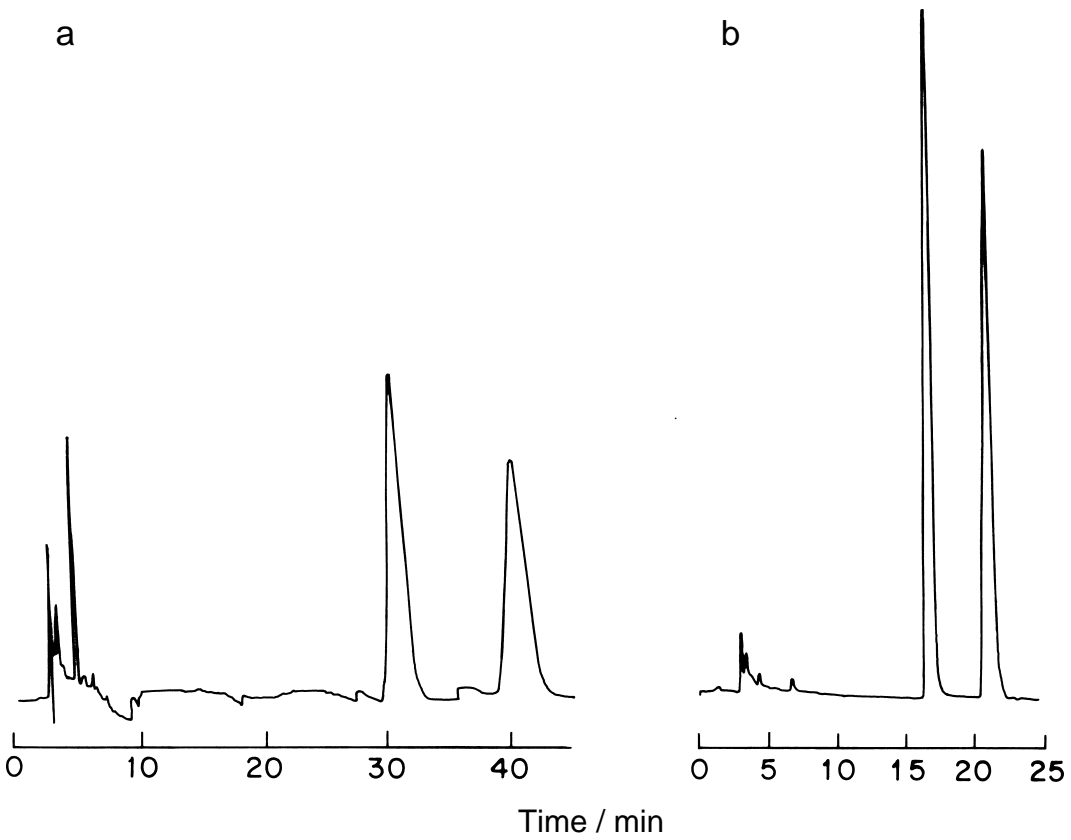

Figure 3. Chiral resolution of carboxyprimaquine on (a) CHIRALCEL OJ and (b) CHIRALCEL OJ-R columns. Mobile phase: (a) hexane:ethanol $(95: 5, \mathrm{v} / \mathrm{v})+0.1 \%$ TFA, at a flow rate of $1.2 \mathrm{~mL} \mathrm{~min}^{-1}$; detection at $254 \mathrm{~nm}$. (b) $\mathrm{NaClO}_{4} 0.3 \mathrm{~mol} \mathrm{~L}^{-1}, \mathrm{pH} 5.0$ :acetonitrile (70:30, v/v) at a flow rate of $0.6 \mathrm{~mL} \mathrm{~min}^{-1}$; detection at $254 \mathrm{~nm}$ 


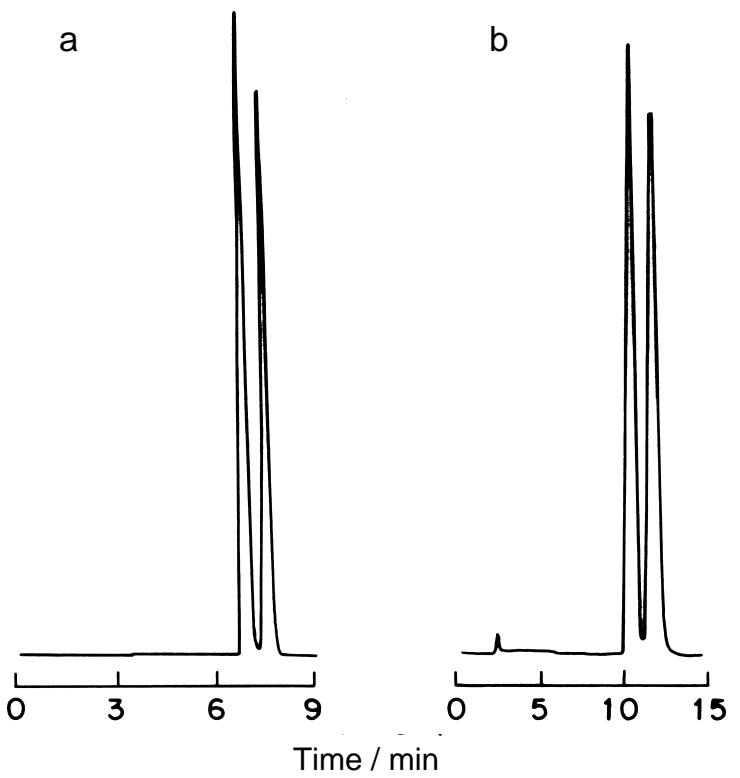

Figure 4. Chiral resolution of (a) thioridazine on CHIRALPAK AD column and (b) thioridazine-2-sulfone on CHIRALCEL OD-H column. Mobile phase: (a) hexane: ethanol $(98: 2, \mathrm{v} / \mathrm{v})+0.1 \%$ DEA at a flow rate of $1.0 \mathrm{~mL} \mathrm{~min}{ }^{-1}$; detection at $262 \mathrm{~nm}$. (b) hexane:2propanol $(90: 10, \mathrm{v} / \mathrm{v})+0.1 \%$ DEA at a flow rate of $1 \mathrm{~mL} \mathrm{~min}^{-1}$, detection at $262 \mathrm{~nm}$

a

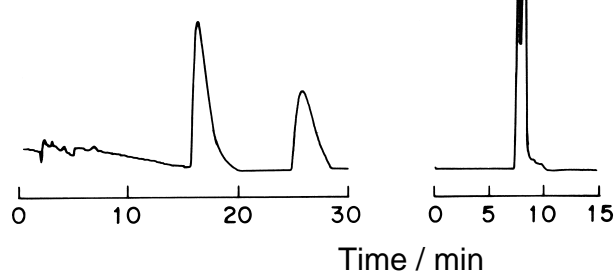

Figure 5. Chiral resolution of thioridazine-5-sulfoxide on (a) CHIRALCEL OD-H and (b) CHIRALCEL OD-R columns and of atenonol on (c) CHIRALCEL OD-H column. Mobile phase: (a) hexane:2-propanol $(90: 10, \mathrm{v} / \mathrm{v})+0.1 \% \mathrm{DEA}$ at a flow rate of 1.0 $\mathrm{mL} \mathrm{min}{ }^{-1}$; detection at $262 \mathrm{~nm}$ (b) $\mathrm{NaClO}_{4} 0.5 \mathrm{~mol} \mathrm{~L}^{-1}, \mathrm{pH}$ 4.0:acetonitrile $(50: 50, \mathrm{v} / \mathrm{v})$ at a flow rate of $0.5 \mathrm{~mL} \mathrm{~min}^{-1}$; detection at $262 \mathrm{~nm}$. (c) hexane:ethanol $(80: 20, \mathrm{v} / \mathrm{v})+0.1 \%$ DEA at a flow rate of $1.0 \mathrm{~mL} \mathrm{~min}^{-1}$; detection at $274 \mathrm{~nm}$

to the procedure described by Cass et al., ${ }^{15}$ the resolution of primaquine and carboxiprimaquine was drastically improved when compared to CHIRALCEL OD-R column (Figure 6). This result could be explained by the difference in the particle size for the stationary phase on both columns, $5 \mu \mathrm{m}$ and $10 \mu \mathrm{m}$, respectively.

The CHIRALPAK AS column, another amylose based chiral stationary phase (tris $((\mathrm{S})-\alpha$-methylbenzyl-
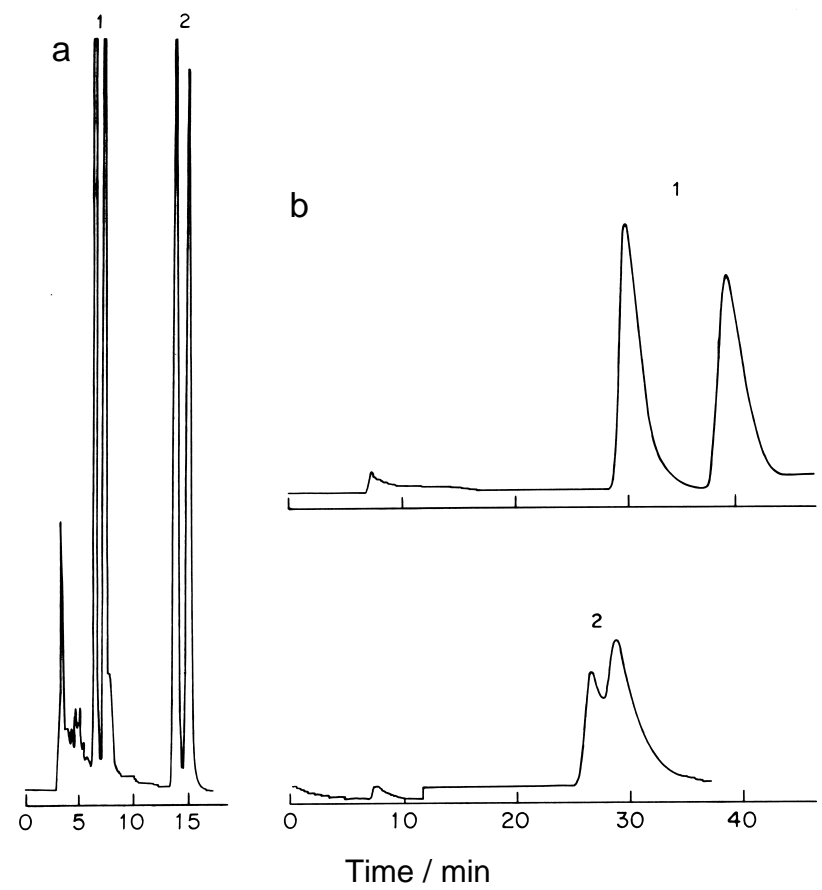

Figure 6. Chiral resolution of primaquine (1) and carboxiprimaquine (2) on (a) CHIRALCEL OD-H and (b) CHIRALCEL OD-R columns under reversed phase conditions. Mobile phase: (a) $\mathrm{NaClO}_{4} 0.5 \mathrm{~mol}$ $\mathrm{L}^{-1}, \mathrm{pH} 3.0$ :acetonitrile $(65: 35, \mathrm{v} / \mathrm{v})$ at a flow rate of $0.6 \mathrm{~mL} \mathrm{~min}{ }^{-1}$; (b) $\mathrm{NaClO}_{4} 0.5 \mathrm{~mol} \mathrm{~L}^{-1}, \mathrm{pH} 5.0$ :acetonitrile $(70: 30, \mathrm{v} / \mathrm{v})$ at a flow rate of $0.4 \mathrm{~mL} \mathrm{~min}^{-1}$; detection at $264 \mathrm{~nm}$

carbamate)), was also evaluated for the resolution of some drugs and metabolites. The results obtained for omeprazole indicate that, in addition to CHIRALPAK AD, this column is suitable for the resolution of this drug (Figure 7).

Polysaccharide-based stationary phases are used under normal phase conditions, using hexane/ethanol or hexane/ 2-propanol as mobile phase. When the polarity of the mobile phase is increased by increasing the amount of ethanol or 2-propanol, a reduction in the retention factor is observed due to a competition between the solute and the active sites in chiral stationary phases. ${ }^{9}$ These active sites can be also non-chiral, such as residual silanol groups on silica surface and, in this case, a reduction in retention may be observed without a significant change in the enantioselective factor (Table 2). Otherwise, the resolution could be drastically affected by the amount of alcohol.

The mobile phase polarity can also be changed by using different types of alcohol. When the same amount of ethanol and 2-propanol is used, the ethanol- containing mobile phase is more polar and a reduction in retention is normally observed but in some cases an inverse behavior is observed (Table 2). The enantioselective factor and resolution can be severely affected by the type of alcoholic modifier. ${ }^{16}$ The reversal of elution order has also been reported for some drugs, ${ }^{9,17,18}$ a behavior probably 
associated with an alteration of the steric nature of the chiral stationary phase. ${ }^{9,19,20}$ Sometimes the simultaneous use of two alcoholic modifiers is advantageous to obtain chiral resolution (Figure 8).

Another important factor affecting retention and chiral resolution is the presence of acidic or basic additives in the mobile phase. Diethylamine (DEA) and trifluoracetic acid (TFA) are frequently added to the mobile phase in

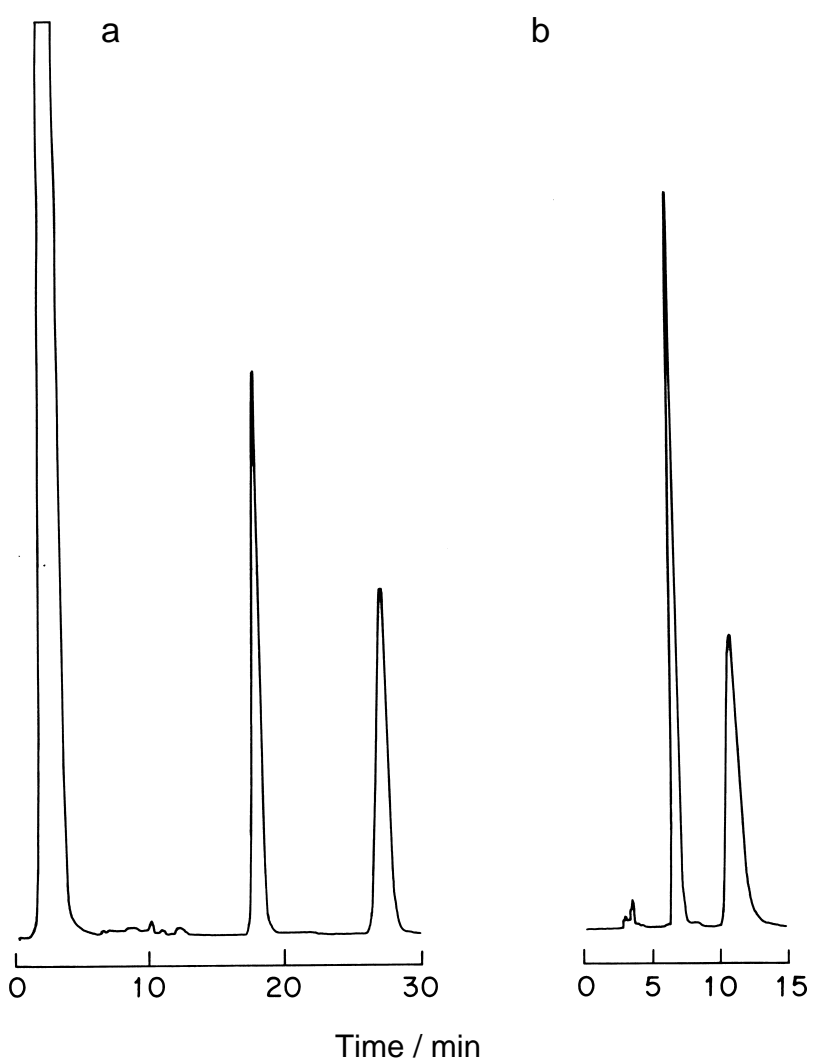

Figure 7. Chiral resolution of omeprazole on (a) CHIRALPAK AD column and (b) CHIRALPAK AS column. Mobile phase: (a) hexane:ethanol $(40: 60, \mathrm{v} / \mathrm{v})$ at a flow rate of $0.5 \mathrm{~mL} \mathrm{~min}^{-1}$; detection at $302 \mathrm{~nm}$. (b) hexane:ethanol $(80: 20, \mathrm{v} / \mathrm{v})$ at a flow rate of $1.5 \mathrm{~mL}$ $\mathrm{min}^{-1}$, detection at $302 \mathrm{~nm}$ order to suppress tailing of basic and acid drugs. Figure 9 shows the results obtained for the analysis of mefloquine on the CHIRALPAK AS column. In the absence of additives, mefloquine did not elute from the column. Enough resolution and good peak shape were obtained by using $0.1 \%$ DEA. Further increments in DEA amount did not change the retention or selective factor significantly. Although mefloquine is a basic compound, a higher enantioselective factor was obtained by using TFA in the mobile phase but, in this case, the second enantiomer eluted as a broader peak. This mechanism might be due to the fact that TFA masked silanol groups in the stationary phase by H-bonding and also resulted in the formation of an ionic par with the basic compound. ${ }^{19,20}$

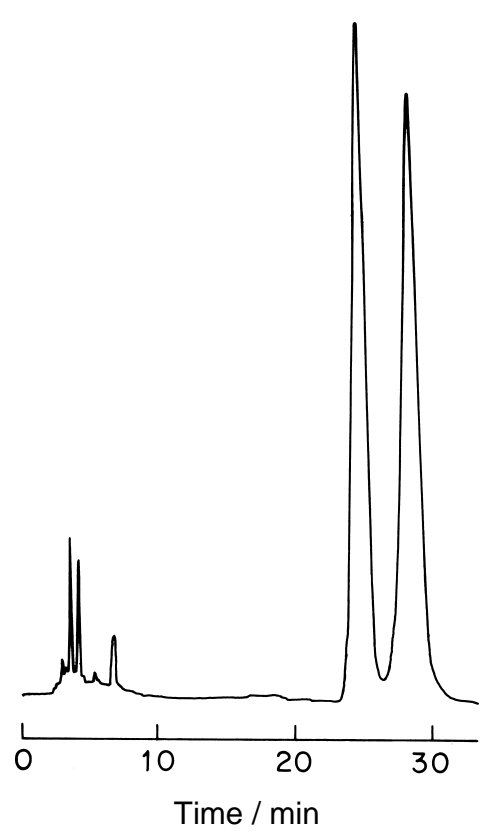

Figure 8. Chiral resolution of hydroxymebendazole on CHIRALPAK AD column. Mobile phase: hexane:2-propanol:ethanol (81:14:5, v/ $\mathrm{v} / \mathrm{v})$ at a flow rate of $1.3 \mathrm{~mL} \mathrm{~min}^{-1}$; detection at $290 \mathrm{~nm}$

Table 2. Influence of the alcoholic modifier on the resolution of thioridazine and its metabolites on CHIRALPAK AD column

\begin{tabular}{|c|c|c|c|c|c|c|c|c|c|c|c|c|}
\hline \multirow[t]{2}{*}{ Mobile phase composition } & \multicolumn{3}{|c|}{ THD } & \multicolumn{3}{|c|}{ THD $2-\mathrm{SO}_{2}$} & \multicolumn{3}{|c|}{ THD 2-SO } & \multicolumn{3}{|c|}{ THD 5-SO } \\
\hline & $\mathrm{k}_{1}$ & $\alpha$ & Rs & $\mathrm{k}_{1}$ & $\alpha$ & Rs & $\mathrm{k}_{1}$ & $\alpha$ & Rs & $\mathrm{k}_{1}$ & $\alpha$ & Rs \\
\hline \multicolumn{13}{|c|}{$\begin{array}{l}\text { Percentage of ethanol } \\
\text { hexane:ethanol }+0.1 \% \text { DEA }\end{array}$} \\
\hline $98: 02$ & 1.35 & 1.15 & 1.50 & 10.27 & 1.00 & 0.0 & 8.57 & 1.35 & 2.61 & - & - & - \\
\hline $90: 10$ & 0.71 & 1.00 & 0.0 & 4.03 & 1.00 & 0.0 & 2.89 & 1.36 & 4.00 & 8.14 & 1.16 & 2.23 \\
\hline \multirow{2}{*}{\multicolumn{13}{|c|}{$\begin{array}{l}\text { Type of the alcohol } \\
\text { Hexane } \cdot \text { alcohol }(90 \cdot 10)+01 \% \text { DEA }\end{array}$}} \\
\hline Hexane:alcohol(90:10) & & & & & & & & & & & & \\
\hline 2-propanol & 0.46 & 1.00 & 0.0 & 2.64 & 1.05 & 0.66 & 2.39 & 1.12 & 1.00 & 8.99 & 1.23 & 2.00 \\
\hline ethanol & 0.71 & 1.00 & 0.0 & 4.03 & 1.00 & 0.0 & 2.89 & 1.36 & 4.00 & 8.14 & 1.16 & 2.23 \\
\hline
\end{tabular}

THD, thioridazine; THD-2-SO ${ }_{2}$, thioridazine-2-sulfone; THD-2-SO, thioridazine-2-sulfoxide; THD-5-SO, thioridazine-5-sulfoxide; -, the enantiomers did not elute in $60 \mathrm{~min} ; \mathrm{k}_{1}$, retention factor for the first eluted enantiomer; $\alpha$, enantioselective factor; Rs, resolution; $\mathrm{t}_{\mathrm{o}}=3.2 \mathrm{~min}$. 
As already pointed out, polysaccharide-based stationary phases can also be used under reversed phase conditions. Neutral compounds could be resolved by using acetonitrile: water as the mobile phase, whereas for the analysis of basic compounds a salt such as sodium perchlorate is generally required. According to Ishikawa \& Shibata, ${ }^{21}$ there is a formation of an ion pair between the basic compound and the perchlorate anion. Acid compounds require acidification of the mobile phase in order to reduce the ionization of

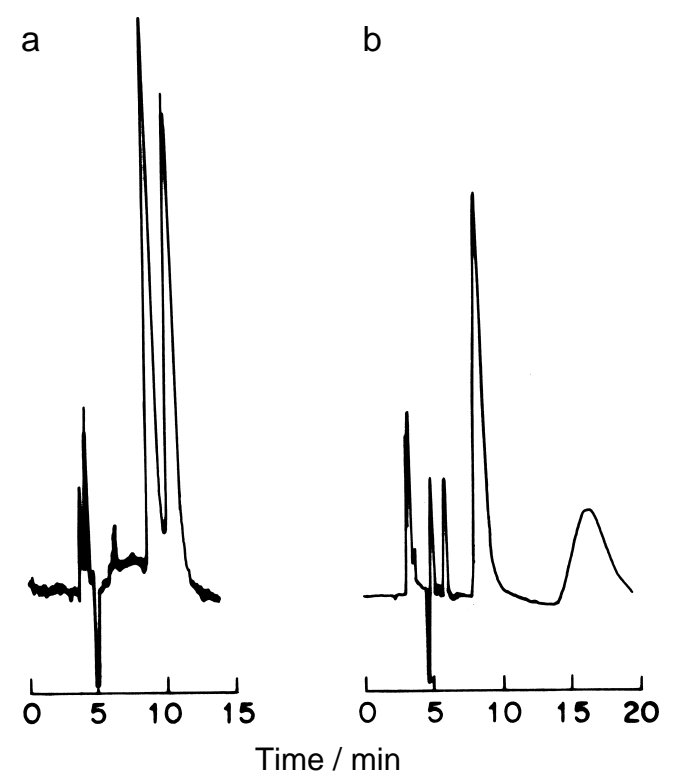

Figure 9. Chiral resolution of mefloquine on CHIRALPAK AS column. Mobile phase: (a) hexane:2-propanol $(98: 2$, v/v) $+0.1 \%$ DEA at a flow rate of $1 \mathrm{~mL} \mathrm{~min}{ }^{-1}$, detection at $220 \mathrm{~nm}$. (b) hexane:2propanol $(95: 5, \mathrm{v} / \mathrm{v})+0.1 \%$ TFA at a flow rate of $1 \mathrm{~mL} \mathrm{~min} \mathrm{~m}^{-1}$, detection at $220 \mathrm{~nm}$ acidic groups. The results obtained for the analysis of primaquine and carboxyprimaquine on CHIRALCEL OD$\mathrm{R}$ column are shown in Table 3 .

The retention of primaquine, an amphiphatic drug $^{22}$ ( $\mathrm{pKa}=3.2$ and 10.4) is increased by increasing the $\mathrm{pH}$ and perchlorate concentration. These results are in agreement with the formation of an ion pair with the perchlorate anion. The increasing effect on the retention factor observed when the amount of acetonitrile in the mobile phase is reduced is a result of an increase in hydrophobic interactions with the chiral stationary phase.

Carboxyprimaquine is an amphoteric drug ${ }^{23}$ in which the quinoline nitrogen has a weak base pKa of 3.2 and the carboxylic acid has a pKa of 3.1. Due to this the retention factors and resolution were highly influenced by the mobile phase $\mathrm{pH}$. An increase in the mobile phase $\mathrm{pH}$ resulted in a reduction in the retention factor as a result of the ionization of the carboxylic acid moiety.

\section{Protein-based chiral stationary phases}

Among the several protein-based chiral columns commercially available, CHIRAL AGP and ULTRON ESOVM are of special interest because of their long term stability and because they are suited for the resolution of a wide range of racemates. ${ }^{24,25}$ The chiral selector in the CHIRAL AGP column is the $\alpha$-1-acid glycoprotein which contains a single 181 amino acid residue polypeptide, two disulfide bonds, and five carbohydrate chains. The protein's molecular weight is $40-44 \mathrm{kDa}$ with $40-45 \%$ of the total mass attributed to the carbohydrate chains situated on the outside of the protein. ${ }^{26}$ The ULTRON ES-

Table 3. Influence of mobile phase composition on the resolution of primaquine and carboxyprimaquine on CHIRALCEL OD-R column

\begin{tabular}{|c|c|c|c|c|c|c|}
\hline \multirow[t]{2}{*}{ Mobile phase composition } & \multicolumn{3}{|c|}{ PQ } & \multicolumn{3}{|c|}{ CPQ } \\
\hline & $\mathrm{k}_{1}$ & $\alpha$ & Rs & $\mathrm{k}_{1}$ & $\alpha$ & Rs \\
\hline \multicolumn{7}{|l|}{$\mathrm{pH}$} \\
\hline \multicolumn{7}{|c|}{$\mathrm{NaClO}_{4} 0.1 \mathrm{~mol} \mathrm{~L}^{-1}$-acetonitrile $(70: 30, \mathrm{v} / \mathrm{v})$} \\
\hline 3.0 & 1.02 & 1.41 & 1.16 & 7.21 & 1.10 & 2.68 \\
\hline 4.0 & 1.90 & 1.40 & 1.70 & 4.54 & 1.14 & 0.42 \\
\hline 5.0 & 2.19 & 1.34 & 1.56 & 2.33 & 1.09 & 0.36 \\
\hline \multicolumn{7}{|c|}{$\mathrm{NaClO}_{4}$ concentration $\left(\mathrm{mol} \mathrm{L}^{-1}\right)$} \\
\hline \multicolumn{7}{|c|}{$\mathrm{NaClO}_{4}$ pH 5.0-acetonitrile $(70: 30, \mathrm{v} / \mathrm{v})$} \\
\hline 0.1 & 2.19 & 1.34 & 1.56 & 2.33 & 1.09 & 0.36 \\
\hline 0.3 & 2.76 & 1.38 & 1.88 & 2.49 & 1.10 & 0.30 \\
\hline 0.5 & 3.08 & 1.39 & 2.19 & 2.57 & 1.10 & 0.47 \\
\hline \multicolumn{7}{|c|}{ Percentage of acetonitrile } \\
\hline \multicolumn{7}{|c|}{$\mathrm{NaClO}_{4} 0.5 \mathrm{~mol} \mathrm{~L}^{-1}, \mathrm{pH} 5.0$-acetonitrile (v/v) } \\
\hline $28^{4}$ & 3.73 & 1.38 & 1.98 & 3.19 & 1.12 & 0.35 \\
\hline 30 & 3.08 & 1.39 & 2.11 & 2.57 & 1.10 & 0.47 \\
\hline 32 & 1.91 & 1.40 & 1.44 & 2.17 & 1.10 & 0.37 \\
\hline
\end{tabular}

PQ, primaquine; $\mathrm{CPQ}$, carboxyprimaquine; $\mathrm{k}_{1}$, retention factor for the first eluted enantiomer; $\alpha$, enantioselective factor; Rs, resolution; $\mathrm{t}_{\mathrm{o}}=8.4$ $\min$. 

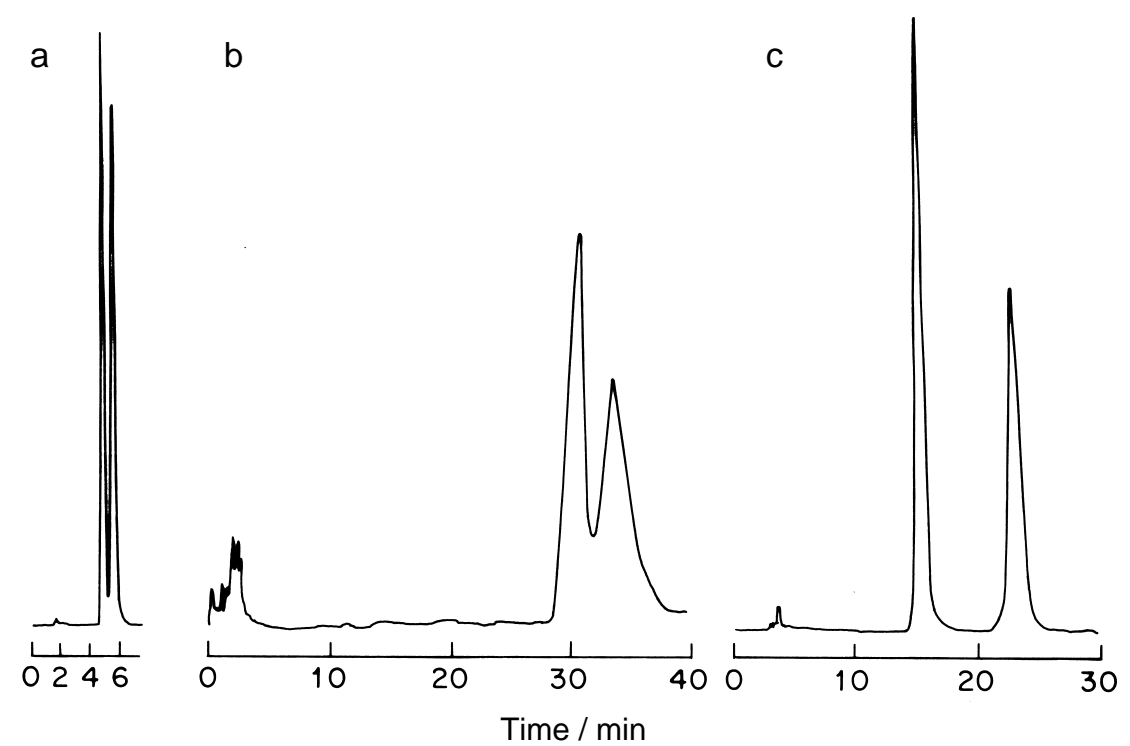

Figure 10. Chiral resolution of (a) thioridazine-5-sulfoxide, (b) primaquine on CHIRAL AGP column and of primaquine (c) on ULTRON ESOVM column. Mobile phase: (a) sodium acetate $0.1 \mathrm{~mol} \mathrm{~L}^{-1}, \mathrm{pH} 5.0$ :acetonitrile $(90: 10 \mathrm{v} / \mathrm{v})$ at a flow rate of $0.9 \mathrm{~mL} \mathrm{~min}^{-1}$, detection at $274 \mathrm{~nm}$. (b) phosphate buffer $50 \mathrm{mmol} \mathrm{L}^{-1}, \mathrm{pH} 7.0: 1$-propanol $(95: 5, \mathrm{v} / \mathrm{v})$ at a flow rate of $0.7 \mathrm{~mL} \mathrm{~min}^{-1}$, detection at $254 \mathrm{~nm}$. (c) phosphate buffer 50 mmol L-1, $\mathrm{pH}$ 6.0:acetonitrile (90:10, v/v) at a flow rate of $0.7 \mathrm{~mL} \mathrm{~min}^{-1}$, detection at $254 \mathrm{~nm}$

OVM column is based on a chicken ovomucoid protein ${ }^{6}$ with a molecular weight of $28 \mathrm{kDa}$ and isoeletric point (pI) of 4.5.

Except for thioridazine-2-sulfone (and hydroxymebendazole that was not evaluated), all other drugs and metabolites were at least partially resolved on the CHIRAL AGP column (Table 1 and Figure 10). The chiral discrimination ability changed with the type of protein bound to the silica matrix. The use of the CHIRAL AGP column resulted in complete resolution of thioridazine-5-sulfoxide enantiomers. However, primaquine was only completely resolved on the ULTRON-ES OVM column. In addition, this column allowed the resolution of the four enantiomers of thioridazine-2-sulfoxide, a thioridazine metabolite with two chiral centers (Figure 11).

The enantiomer separation in protein-based chiral stationary phases is highly influenced by mobile phase composition. In this paper we report the results of retention, enantioselective factor and resolution of primaquine and carboxyprimaquine on the ULTRON ES-OVM column (Table 4). The retention and resolution of these drugs were highly dependent on mobile phase $\mathrm{pH}$. The ovomucoid protein has an isoeletric point of 4.5 and is therefore expected to have a net negative charge above this $\mathrm{pH}$ and a positive charge below it. Primaquine is a basic drug and is expected to be protonated throughout the $\mathrm{pH}$ range evaluated. When the $\mathrm{pH}$ is increased, the ionic interaction with the protein is also increased, resulting in an increase in retention factor. Probably, the changes in $\mathrm{pH}$ also induce conformational changes in the protein, resulting in differences in the

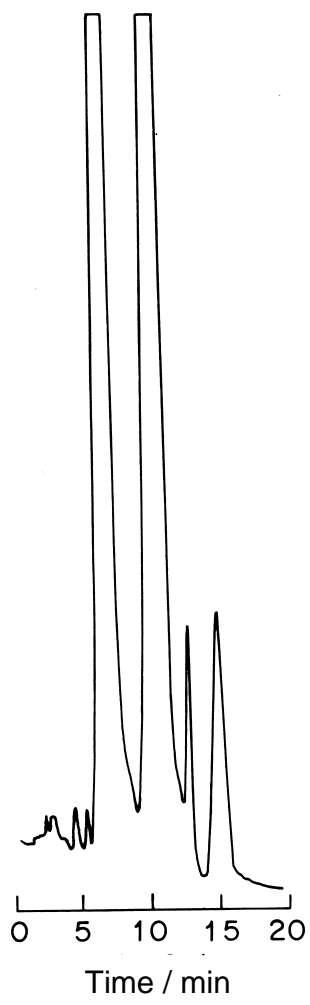

Figure 11. Chiral resolution of thioridazine-2-sulfoxide on ULTRON ES-OVM column. Mobile phase: Sodium acetate $0.1 \mathrm{~mol} \mathrm{~L}^{-1}, \mathrm{pH}$ 3.5:acetonitrile $(95: 5, \mathrm{v} / \mathrm{v})$ at a flow rate of $0.9 \mathrm{~mL} \mathrm{~min}^{-1}$, detection at $262 \mathrm{~nm}$

enantioselective factors and resolution. ${ }^{27}$ The ion exchange effect was also observed when the buffer concentration was modified. The influence of mobile phase $\mathrm{pH}$ on retention 
Table 4. Influence of mobile phase composition on the resolution of primaquine and its metabolite on ULTRON ES OVM column

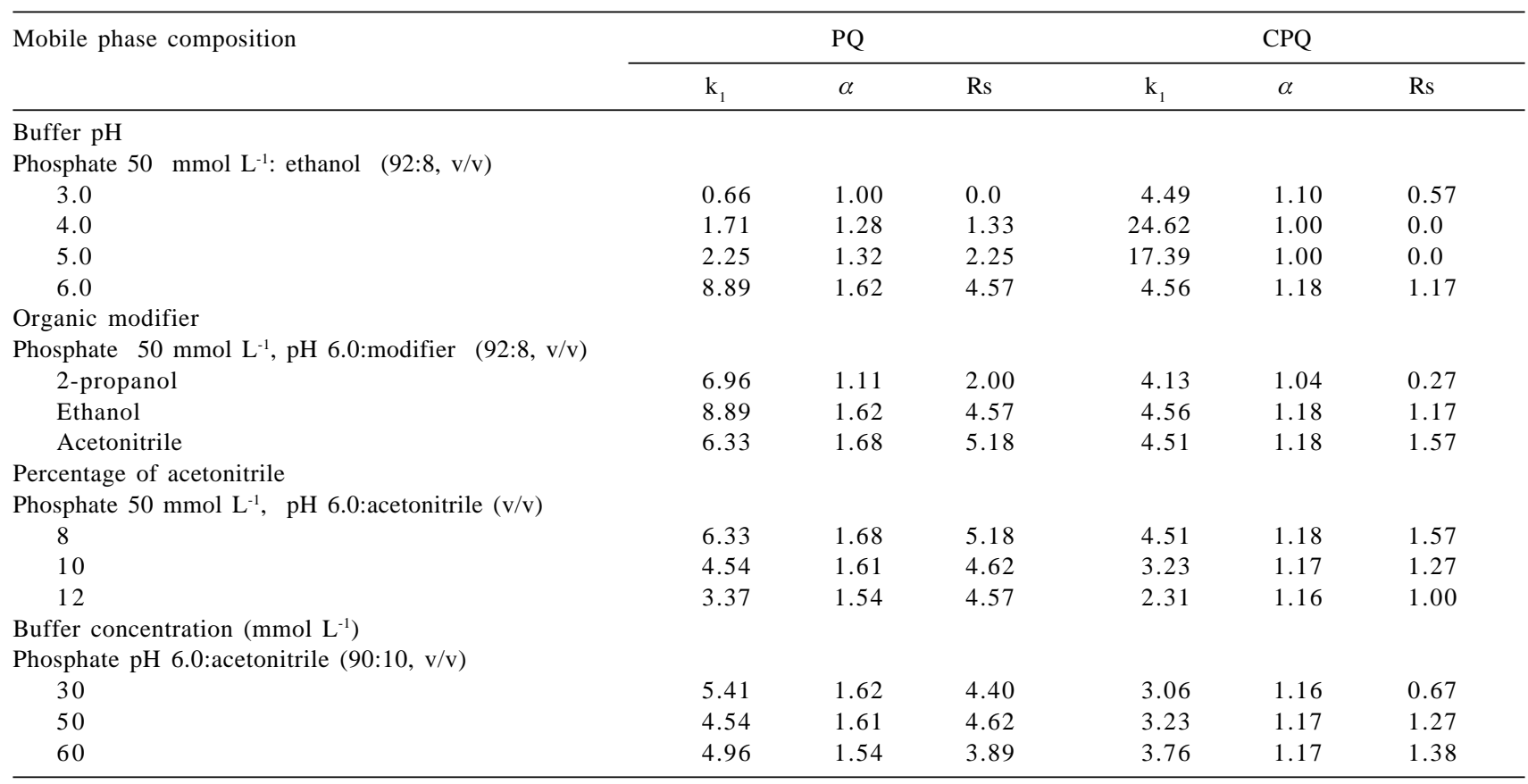

$\mathrm{PQ}$, primaquine; $\mathrm{CPQ}$, carboxyprimaquine; $\mathrm{k}_{1}$, retention factor for the first eluted enantiomer; $\alpha$, enantioselective factor; Rs, resolution; $\mathrm{t}_{\mathrm{o}}=2.1$ $\min$.

and separation of carboxyprimaquine enantiomers was highly significant. The retention increased up to $\mathrm{pH} 4.0$ due to electrostatic interaction between the negatively charged drug and positive sites on the protein surface. When the mobile phase $\mathrm{pH}$ was increased, the protein surface became more and more negatively charged and the retention of carboxyprimaquine decreased. In spite of this reduction in the retention factors, the resolution of carboxyprimaquine enantiomers was only possible at $\mathrm{pH}$ 6.0.

Protein-based chiral stationary phases are used with mobile phases consisting of a buffer solution supplemented with an organic modifier in order to reduce the hydrophobic interaction. The retention of primaquine and carboxyprimaquine increased by increasing the polarity of the mobile phase, which was done by changing the type of organic modifier or the percentage of acetonitrile. The amount and kind of organic modifier may also affect the binding properties of the protein. ${ }^{28}$

\section{Conclusions}

The chiral resolution of some drugs and metabolites was evaluated in polysaccharide- and protein-based stationary phases. The polysaccharide-based stationary phases, particularly the CHIRALPAK AD column, showed high chiral discrimination ability, being suitable for the resolution of almost all drugs and metabolites evaluated. The kind of alcoholic modifier and acid or basic additives in the mobile phase are the major factors affecting resolution. Among the protein-based chiral stationary phases, the ULTRON ES-OVM column was good enough for the resolution of four enantiomers of thioridazine-2sulfoxide. The resolution was mainly affected by mobile phase $\mathrm{pH}$ and type of organic solvents.

\section{Acknowledgments}

The authors are grateful to FAPESP (Fundação de Amparo a Pesquisa do Estado de São Paulo), CNPq (Conselho Nacional de Desenvolvimento Científico e Tecnológico) and CAPES (Coordenação de Aperfeiçoamento de Pessoal de Nível Superior) for financial support and for granting research fellowships.

\section{References}

1. Caldwell, J.; J. Chromatogr., A 1995, 694, 39.

2. Caldwell, J.; J. Chromatogr., A 1996, 719, 3.

3. Williams, R. C.; Riley, C. M.; Sigvardson, K. W.; Fortunak, J.; Ma, P.; Nicolas, E. C.; Unger, S. E.; Krahn, D. F.; Bremner, S. L.; J. Pharm. Biomed. Anal. 1998, 17, 917.

4. Okamoto, Y.; Kaida, Y.; J. Chromatogr., A 1994, 666, 403.

5. Oguni, K.; Oda, H.; Ichida, A.; J. Chromatogr., A 1995, 694, 91

6. Allenmark, S. G.; Andersson, S.; J. Chromatogr., A 1994, $666,167$. 
7. Francotte, E.; J. Chromatogr., A 1994, 666, 565.

8. Yashima, E.; Okamoto, Y.; Bull. Chem. Soc. Jpn. 1995, 68, 3289.

9. Wang, T.; Chen, Y. W.; J. Chromatogr., A 1999, 855, 411.

10. Fornstedt, T.; Sajonz, P.; Guiochon, G.; Chirality 1998, 10, 375.

11. Gyimesi-Forrás, K.; Szász, G.; Budvári-Bárány, Z.; Gergely, A.; Chirality 1999, 11, 212.

12. Haginaka, J.; Kagawa, C.; Matsunaga, H.; J. Chromatogr., A 1999, 858,155 .

13. Waters, M. S.; Sidler, D. R.; Simon, A. J.; Middaugh, C. R.; Thompson, R.; August, L. J.; Bicker, G.; Perpall, H. J.; Grinberg, N.; Chirality 1999, 11, 224.

14. Steinmeier, H.; Zugenmaier, P.; Carb. Res. 1987, 164, 97.

15. Cass, Q. B.; Degani, A. L.G.; Cassiano, N.; J. Liq. Chromatogr. Relat. Technol. 2000, 23, 1029.

16. Bonato, P. S.; Lanchote, V. L.; Bortocan, R.; Jabor, V. A. P.; Paias, F. O.; Ricci-Júnior, E.; Carvalho, R.; J. Liq. Chromatogr. Relat. Technol. 1999, 22, 1813.

17. Okamoto, M.; Nakazawa, H.; J. Chromatogr. 1991, 588, 177.

18. Balmér, K.; Lagerström, P.; Persson, B. Schill, G.; J. Chromatogr. 1992, 592, 331.
19. Tang, Y.; Chirality 1996, 8, 136.

20. Kunath, A.; Theil, F.; Jähnisch, K.; J. Chromatogr., A 1996, $728,249$.

21. Ishikawa, A.; Shibata, T.; J. Liq. Chromatogr. 1993, 16, 859.

22. Stensrud, G.; Sande, S. A.; Kristensen, S.; Smistad, G.; Int. J. Pharm. 2000, 198, 213.

23. Idowu, O. R.; Peggins, J.O.; Brewer, T.G.; Drug Metab. Dispos. 1995, 23, 18.

24. Rudaz, S.; Veuthey, J.; Chirality 1999, 11, 319.

25. Haginaka, J.; Seyama, C.; Murashima, T.; J. Chromatogr., A 1995, 704, 279.

26. Aubert, J.; Biserte, G.; Loucheux-Lefebvre, M.; Arch. Biochem. Biophys. 1976, 175, 410.

27. Nyström, A.; Karlsson, A.; J. Chromatogr., A 1997, 763, 105.

28. Mano, N.; Oda, Y.; Asakawa, N.; Yoshida, Y.; Sato, T.; Miwa, T.; J. Chromatogr., A 1994, 687, 223.

Received: February 5, 2001

Published on the web: February 8, 2002

FAPESP helped in meeting the publication costs of this article. 